\title{
Advances in Metal Supported Cells in the METSOFC EU Consortium
}

McKenna, Brandon J.; Christiansen, Niels; Schauperl, Richard; Prenninger, Peter; Nielsen, Jimmi; Blennow Tullmar, Peter; Klemensø, Trine; Ramousse, Severine; Kromp, Alexander; Weber, André

\section{Published in:}

Proceedings

Publication date:

2012

Document Version

Publisher's PDF, also known as Version of record

Link back to DTU Orbit

Citation (APA):

McKenna, B. J., Christiansen, N., Schauperl, R., Prenninger, P., Nielsen, J., Blennow Tullmar, P., Klemensø, T., Ramousse, S., Kromp, A., \& Weber, A. (2012). Advances in Metal Supported Cells in the METSÖFC EU Consortium. In Proceedings (pp. A0903). European Fuel Cell Forum.

\section{General rights}

Copyright and moral rights for the publications made accessible in the public portal are retained by the authors and/or other copyright owners and it is a condition of accessing publications that users recognise and abide by the legal requirements associated with these rights.

- Users may download and print one copy of any publication from the public portal for the purpose of private study or research.

- You may not further distribute the material or use it for any profit-making activity or commercial gain

- You may freely distribute the URL identifying the publication in the public portal 


\title{
Advances in Metal Supported Cells in the METSOFC EU Consortium
}

\author{
Brandon J. McKenna (1), Niels Christiansen (1), Richard Schauperl (2), Peter \\ Prenninger (2), Jimmi Nielsen (3), Peter Blennow (3), Trine Klemensø (3), Severine \\ Ramousse (3), Alexander Kromp (4), André Weber (4) \\ (1)Topsoe Fuel Cell A/S, Nymøllevej 66, DK-2800 Lyngby, Denmark \\ (2) AVL List Gmbh, Hans-List-Platz 1, 8020 Graz, Austria \\ (3) Department of Energy Conversion and Storage, Technical University of Denmark, \\ Frederiksborgvej 399, DK-4000 Roskilde, Denmark \\ (4) Karlsruher Institut für Technologie, Adenauerring 20b, 76131 Karlsruhe, Germany \\ Tel.: +45-4527-8302 \\ brim@topsoe.dk
}

\begin{abstract}
Employing a mechanically robust metal support as the structural element in SOFC has been the objective of various development efforts. The EU-sponsored project "METSOFC", completed at the end of 2011, resulted in a number of advancements towards implementing this strategy. These include robust metal supported cells (MSCs) having low ASR at low temperature, incorporation into small stacks of powers approaching $1 / 2 \mathrm{~kW}$, and stack tolerance to various operation cycles.

DTU Energy Conversion's (formerly Risø DTU) research into planar MSCs has produced an advanced cell design with high performance. The novel approach has yielded roboust, defect-free cells fabricated by a unique and well-tailored co-sintering process. At low operation temperatures $\left(650^{\circ} \mathrm{C}\right)$, these cells have shown remarkable ASRs: $0.35 \Omega \mathrm{cm}^{2}$ in cell tests $\left(16 \mathrm{~cm}^{2}\right.$ active area) and under $0.3 \Omega \mathrm{cm}^{2}$ in button cells $\left(0.5 \mathrm{~cm}^{2}\right.$ active area). Further success was attained with even larger cell areas of $12 \mathrm{~cm}$ squares, which facilitated integration into stacks at Topsoe Fuel Cell. Development of MSC stacks showed that the MSCs could achieve similar or better performance, compared to SoA anode supported ceramic cells. The best stacked MSCs had power densities approaching 275 $\mathrm{mW} / \mathrm{cm}^{2}$ (at $680^{\circ} \mathrm{C}$ and $0.8 \mathrm{~V}$ ). Furthermore, extended testing at AVL determined extra stack performance and reliability characteristics, including behavior towards sulfur and simulated diesel reformate, and tolerance to thermal cycles and load cycles. These and other key outcomes of the METSOFC consortium are covered, along with associated work supported by the Danish National Advanced Technology Foundation.
\end{abstract}




\section{Introduction}

State of the art SOFC technology still encounters critical challenges specifically regarding robustness and reliability. Modeling studies as well as recent practical experience have proven how up-scaling of cells and stacks to larger, more industrially relevant sizes generally lowers real system reliability and tolerance towards uncertainties such as system abuse, long term dynamic operation and operation failures. These observations conform to the statistical distribution of mechanical properties governing the probability of failure of cells based on ceramic materials, whether it is for mobile or for stationary applications.

Metal-supported SOFC stack technology offers an innovative alternative to conventional electrode- and electrolyte-supported SOFCs. Metallic substrate technology has many potential advantages such as improved thermal conductivity and ductility. Such properties ensure safe operation, including thermal shock resistance and tolerance towards internal temperature gradients and operation cycles. Beyond mechanical robustness, the MSC concept is also attractive because such a new platform is expected to yield improvements in cell cost, component handling, operational constraints, and operational temperature, which would also make way for cheaper system and stack components.

Employing a mechanically robust metal support as the structure element in SOFC was the objective of the EU-sponsored METSOFC program, complete at the end of 2011. The METSOFC consortium combined commercial and academic efforts around the EU, covering various levels of the supply chain from metal production to cell fabrication, stacks, and system integration. The partners and consortium details can be found on the webpage http://www.metsofc.eu. We report here most specifically on cell development and stack improvements with metal supported cells, including the results of various stack tests. We also describe, without differentiation, largely overlapping portions financed heavily by the Danish National Advanced Technology Foundation, in the project "Robust Metal-based Fuel Cell Systems for Commercial Applications."

A number of advancements were made from these efforts, towards implementing robust metal supports for SOFC, including low ASR at low temperature, incorporation of cells into small stacks generating nearly $1 / 2 \mathrm{~kW}$, and demonstration of stack tolerance to various operation cycles.

\section{Experiments and Results}

\section{Metal Supported Cell Development}

The main objective for DTU Energy Conversion's (part of former Risø DTU, hereafter referred to as DTU) cell design was to develop robust and corrosion resistant metal supports. Based on a variety of different alloy compositions, metal supports were fabricated with focus on processing compatibility with other cell components, porosity, microstructure, and corrosion resistance. This effort produced an advanced design with high performance. At low operation temperatures $\left(650^{\circ} \mathrm{C}\right)$, these cells have shown remarkable ASRs: $0.35 \Omega \mathrm{cm}^{2}$ in cell tests $\left(16 \mathrm{~cm}^{2}\right.$ active area) and under $0.3 \Omega \mathrm{cm}^{2}$ in button cells $\left(0.5 \mathrm{~cm}^{2}\right.$ active area).

The chosen metal supported cell (MSC) design is based on a multilayered structure obtainable by cost effective ceramic processing techniques such as tape casting, lamination, co-sintering and infiltration. The innovative concept, which ensures that the 
number of different steps in manufacturing is minimized, includes an unconventional half cell design where the major material and durability problems associated by the use of $\mathrm{Ni}$ YSZ anodes are circumvented by the use of an alternative anode structure. The cell design is based on porous and highly electronically conducting layers (FeCr-based metal support and FeCr-YSZ-based anode cermet backbone layer) into which electrocatalytically active anode materials (Gd-doped $\mathrm{CeO}_{2}(\mathrm{CGO})$ and minor amounts of $\mathrm{Ni}$ ) are infiltrated after sintering [1-3], see Figure 1. This novel approach has succeeded in yielding robust, defect-free cells with high performance.

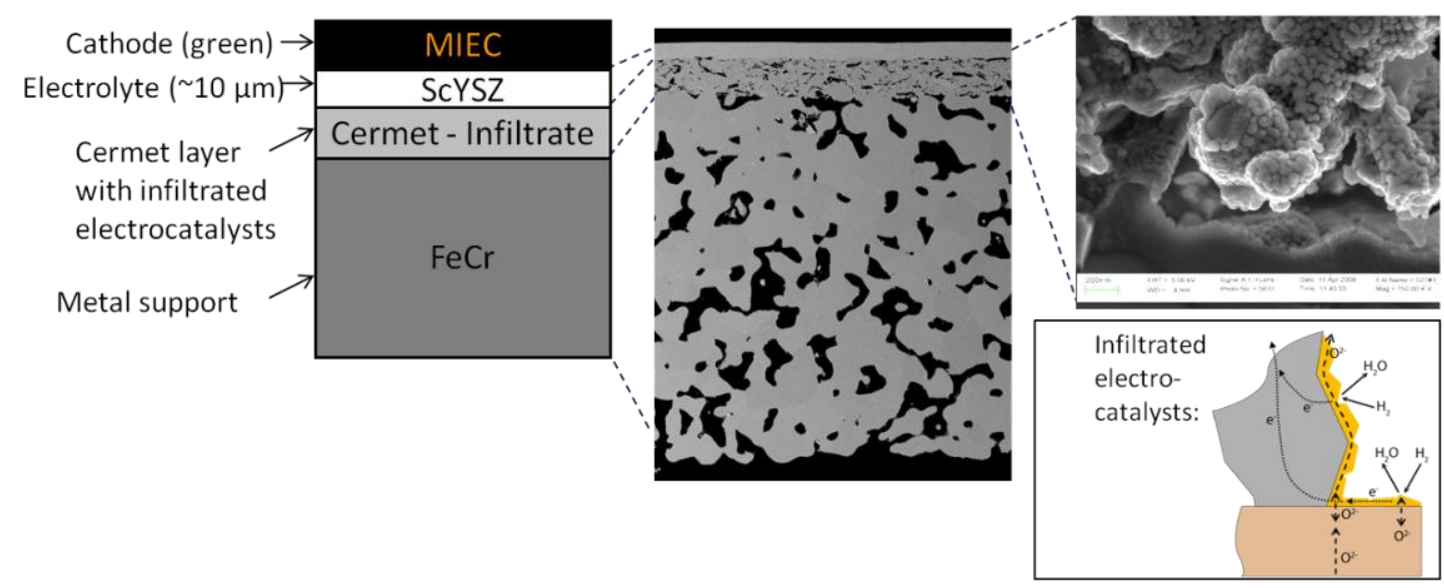

Figure 1: Schematic illustration together with a SEM image showing the concept of the MSC design infiltrated with Ni-CGO

The major advantage of the cell design, developed in the EU project METSOFC and Danish national funded projects (The Danish National Advanced Technology Foundation), is the employment of a unique industrial relevant technology based on one single sintering step of the half cell (metal support, anode layer, and electrolyte). Using only one sintering step in the cell fabrication process is a key factor to keep the production cost at a minimum and to reduce the possibilities of processing related defects. The amount of Ni used for a ceramic anode-supported cell is around $40 \mathrm{wt} \%$ compared to around $0.2-0.5 \mathrm{wt} \%$ for the MSCs developed in the DTU / TOFC consortium. This combined with the fact that approximately $90 \%$ of the weight of an MSC comprises of stainless steel components, points to high potential for increased recycling of materials and lowering of materials cost.

The performance and durability of the MSCs $\left(25 \mathrm{~cm}^{2}\right.$ with an active area of $\left.16 \mathrm{~cm}^{2}\right)$ in various fuels further shows the potential of this cell design concept. Figure 2 illustrates the initial performance of various cells in terms of the corresponding area specific resistances determined under load at a cell voltage of $0.7 \mathrm{~V}$ and an operating temperature of $650{ }^{\circ} \mathrm{C}$ measured for the METSOFC reformate and a $\mathrm{H}_{2} / \mathrm{H}_{2} \mathrm{O}$-containing fuel. These specific cells have been investigated in collaboration with KIT in Germany during the METSOFC project. The gas composition for reformate operation was: cathode $=100 \%$ air, $1000 \mathrm{sccm}$; anode $=17,78 \% \mathrm{H}_{2}, 8.36 \% \mathrm{H}_{2} \mathrm{O}, 14.37 \% \mathrm{CO}, 8.64 \% \mathrm{CO}_{2}, 50.85 \% \mathrm{~N}_{2}, 500 \mathrm{sccm}$. The $\mathrm{H}_{2} / \mathrm{H}_{2} \mathrm{O}$ fuel was applied according to the FCTESTNET $\mathrm{H}_{2}$ testing conditions (cathode $=100 \%$ air, 664 sccm; anode $=97 \% \mathrm{H}_{2}, 3 \% \mathrm{H}_{2} \mathrm{O}, 268 \mathrm{sccm}$ ). 


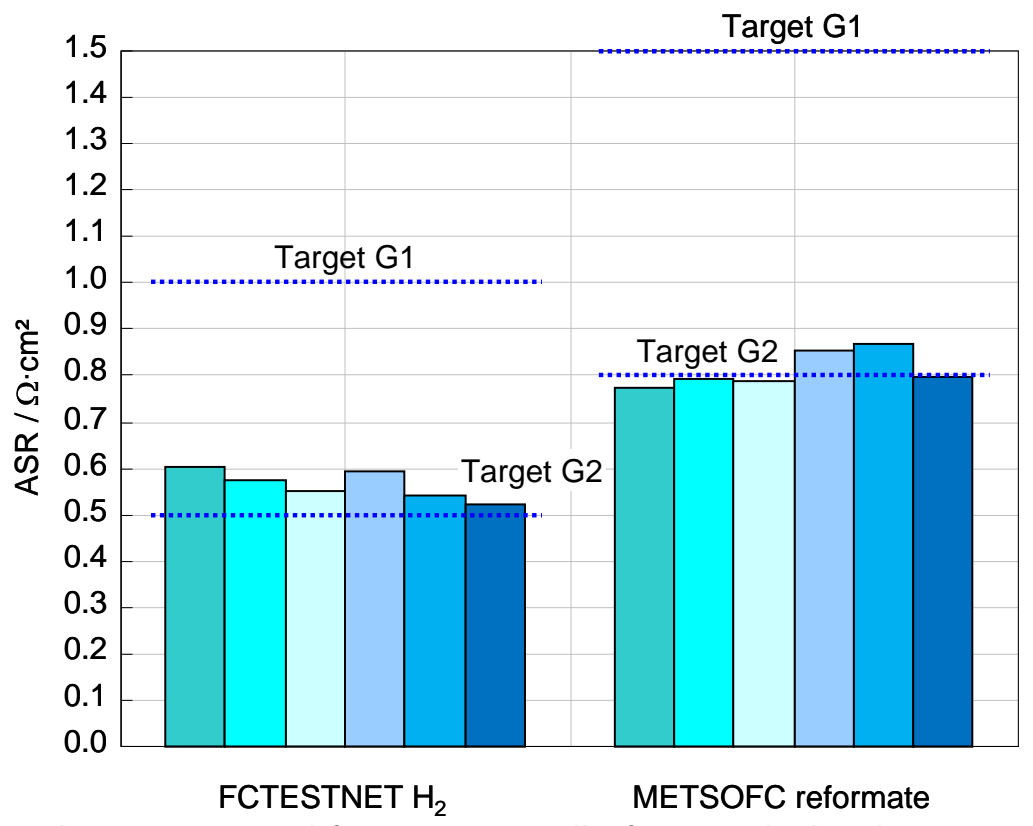

Figure 2: ASR values extracted for $16 \mathrm{~cm}^{2}$ cells from polarization curves recorded at $650^{\circ} \mathrm{C}$ with different fuels (air as oxidant). The blue lines correspond to the performance targets to be achieved in the METSOFC project. The different bars represent various tested cells (with some minor differences in cell microstructure).

The initial performance data in Figure 2 show that the developed MSCs exhibit excellent performance in various fuels. Performance and long term tests carried out at DTU exhibited an identical performance and an excellent stability of the cells in dry $\mathrm{H}_{2}$ at low fuel utilization. Figure 3 gives an overview over the long-term stability tests at DTU. A longterm test of $3000 \mathrm{~h}$ was carried out on an MSC at $650{ }^{\circ} \mathrm{C}$, almost dry $\mathrm{H}_{2}\left(4 \% \mathrm{H}_{2} \mathrm{O}\right)$ and a current load of $0.25 \mathrm{~A} / \mathrm{cm}^{2}$. The cell showed an excellent degradation rate of $0.036 \Omega \cdot \mathrm{cm}^{2}$ and $0.9 \%$ of the cell voltage per $1000 \mathrm{~h}$ (14test101) [3]. At KIT a similar long-term test was carried out on an MSC at a higher current load of $600 \mathrm{~mA} / \mathrm{cm}^{2}$. The tested cell showed no degradation over $2500 \mathrm{~h}$ in air/ $\mathrm{H}_{2}$ at $650{ }^{\circ} \mathrm{C}$. However, as can be seen in the case of test "7test28" in Figure 3, the MSC failed after several hundred hours, if the cell was operated at more "realistic" conditions with $70 \%$ fuel utilization. This is mainly due the accelerated corrosion in the anode layer at high fuel utilization [2]. Currently, a new anode design is being developed in order to circumvent the corrosion of the anode layer. It was recently shown that a ceramic based anode (based on $\mathrm{Nb}$-doped $\mathrm{SrTiO}_{3}$ ) has the potential to avoid detrimental corrosion of the anode layer. However, more work is needed to optimize the microstructure and to investigate the long term stability of these types of cells [4]. 


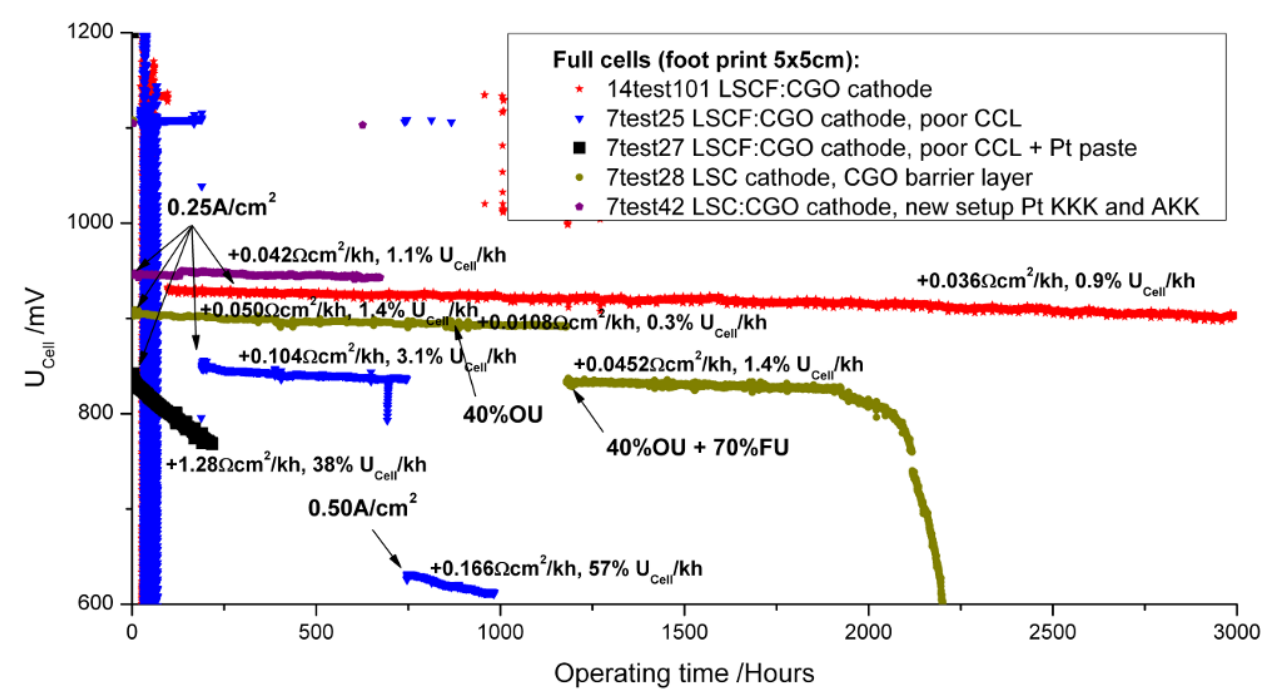

Figure 3: Cell voltage as a function of time at a constant current density of $0.25 \mathrm{~A} / \mathrm{cm}^{2}$ (unless otherwise specified) and a cell temperature of $650^{\circ} \mathrm{C}\left( \pm 5^{\circ} \mathrm{C}\right)$. The fuel was humidified $\mathrm{H}_{2}\left(\sim 4 \% \mathrm{H}_{2} \mathrm{O}\right)$ and the oxidant was air (fuel and oxygen utilizations $<<10 \%$ unless otherwise specified).

In addition to having an electrochemical performance comparable to state-of-the-art ceramic anode supported cells, the MSCs have proved to possess further advantages such as red-ox stability [2] and higher mechanical strength and possibilities of more compact stack assembling by welding or brazing. On full cells $\left(25 \mathrm{~cm}^{2}\right.$ cells with $16 \mathrm{~cm}^{2}$ active area), ASR values of $0.2 \Omega \mathrm{cm}^{2}$ and $\approx 0.5 \Omega \mathrm{cm}^{2}$ has been obtained at $750{ }^{\circ} \mathrm{C}$ and 650 ${ }^{\circ} \mathrm{C}$, respectively [3]. The METSOFC metal support design was further characterized for parabolic oxidation behavior, presenting a rate constant implying lifetimes around 30000 $50000 \mathrm{~h}$ at $650{ }^{\circ} \mathrm{C}$. This oxidation resistance was accomplished with "as-sintered" structures.

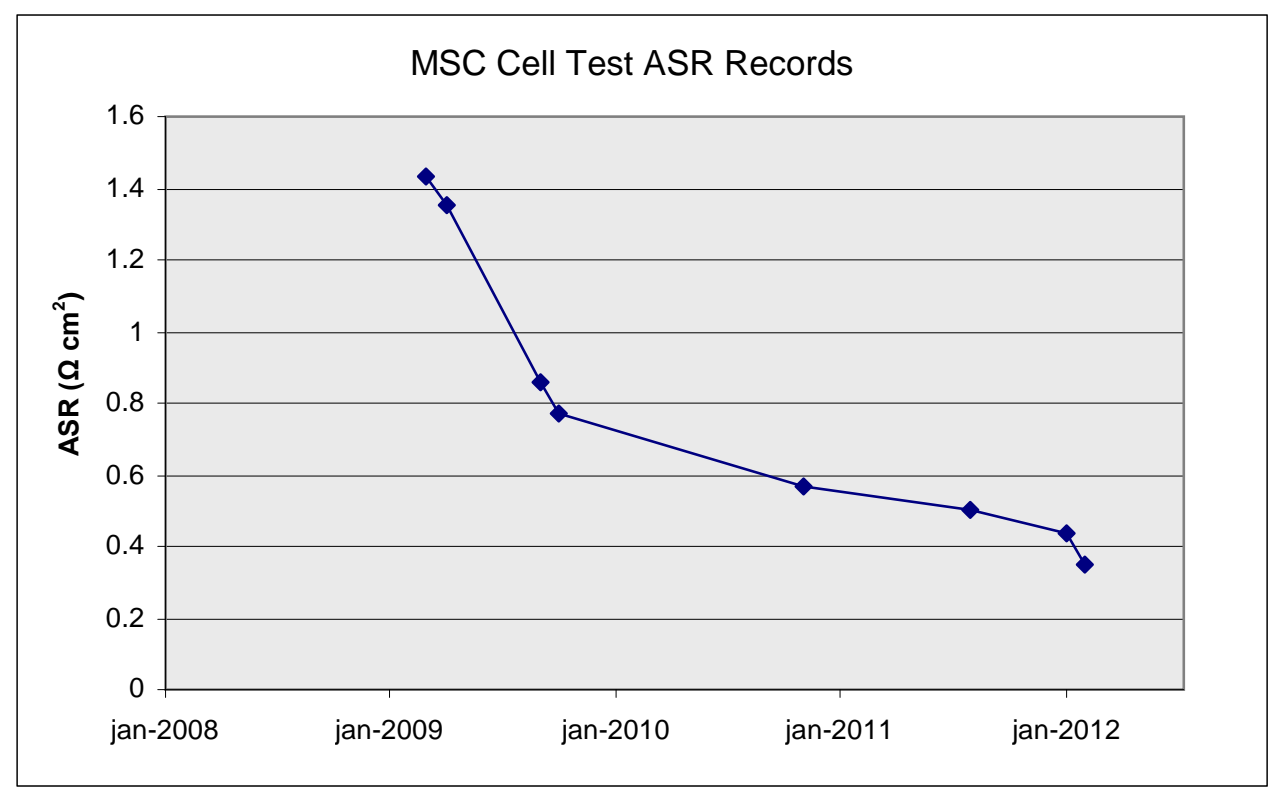

Figure 4: Cell ASR was reduced by more than a factor of 3 during the METSOFC project.

Over the duration of the METSOFC project, improvements to the processing and cell have increased yield, production numbers, size, and performance (Figure 4, above). The inherent ruggedness of MSCs potentially improves the manufacturability, since cells can 
withstand rough or fast handling operations that would normally fracture a ceramic cell. Further success was attained with even larger cell areas of $12 \mathrm{~cm}$ squares, which facilitated integration into stacks at Topsoe Fuel Cell. Development of MSC stacks showed that the MSCs could achieve similar or better performance, compared to SoA anode supported ceramic cells.

\section{Stack development and testing}

The main objective for stack development was to integrate DTU's developed MSCs into the stacks at Topsoe Fuel Cell. Due to significant differences between the properties of MSCs and ceramic cells, the stack construction and conditioning was adapted to accommodate the cells. Therefore, the goals of the project focused on various stack integration parameters, including the sealing methodology, extra cell processing steps, and stack conditioning. The end result was a one-process conditioning step yielding reproducible and high performance stacks containing the MSCs.

The METSOFC work on stacks resulted in many specialized unit tests, improved sealing technology, implementation of a different stack design, and the successful operation of an MSC stack containing 25 cells (Figure 5, below). The best stacked MSCs were operated at power densities approaching $275 \mathrm{~mW} / \mathrm{cm}^{2}$ (at $680{ }^{\circ} \mathrm{C}$ and $0.8 \mathrm{~V}$ ), and these also showed tolerance to thermal cycles and load cycles. These successes were built on developments in: glass materials development, cell-edge sealing, specialized conditioning procedures, brazing, cell defects treatments, revised stack design, treatments to address cathode adhesion, tests of the mechanical integrity of the MSCs, and integration of various new materials and material treatments into the stack.

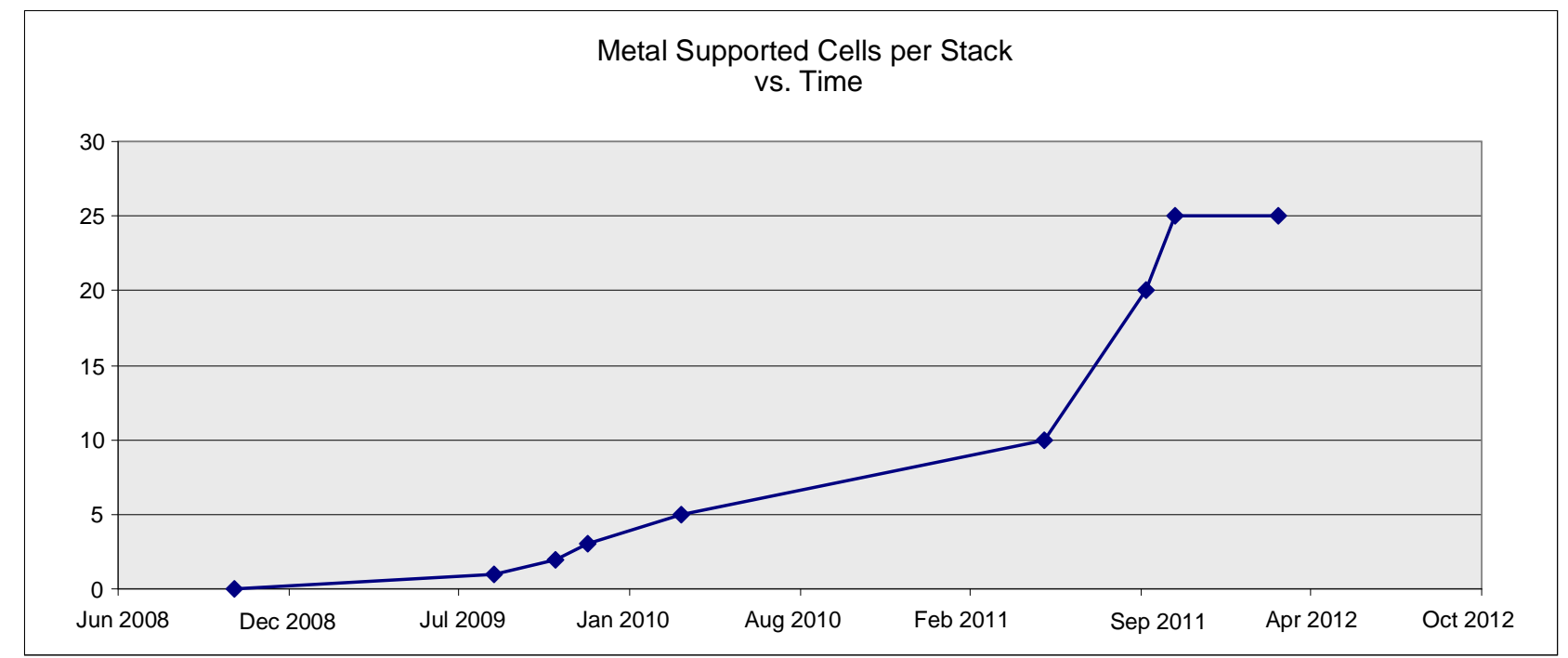

Figure 5: Graph showing the increase in number of stacked MSCs, over the duration of the METSOFC project.

Most stacks were produced to test variations in the conditioning procedure. A viable alternate procedure was first demonstrated on ceramic stacks, and this was subsequently repeated on multiple test stacks containing mixtures of ceramic cells and a few MSCs. The cells in early stack tests were sometimes found with electrolyte microcracks, sufficient cathode adhesion during thermal cycling. Extensive studies combined with post mortem analysis revealed that the applied stack flow configuration had decisive effects on the observed crack initiation. Further modifications proved to prevent electrolyte damage. Stack operation and cycling showed that the cell design in general was quite sensitive to 
cathode adhesion and delamination. Iterations in the development aimed at further increase of robustness.

The improvements to cells, stack components, and conditioning also manifested steadily decreasing ASR from stack to stack, ultimately matching or besting typical ceramic cell performance. Figure 6, below, shows this trend clearly. Additionally, the spread between lowest- and highest-ASR, of cells within the same stack, narrowed with successive stack constructions. By the end of the METSOFC project, the MSCs had achieved reproducible and uniform performance.

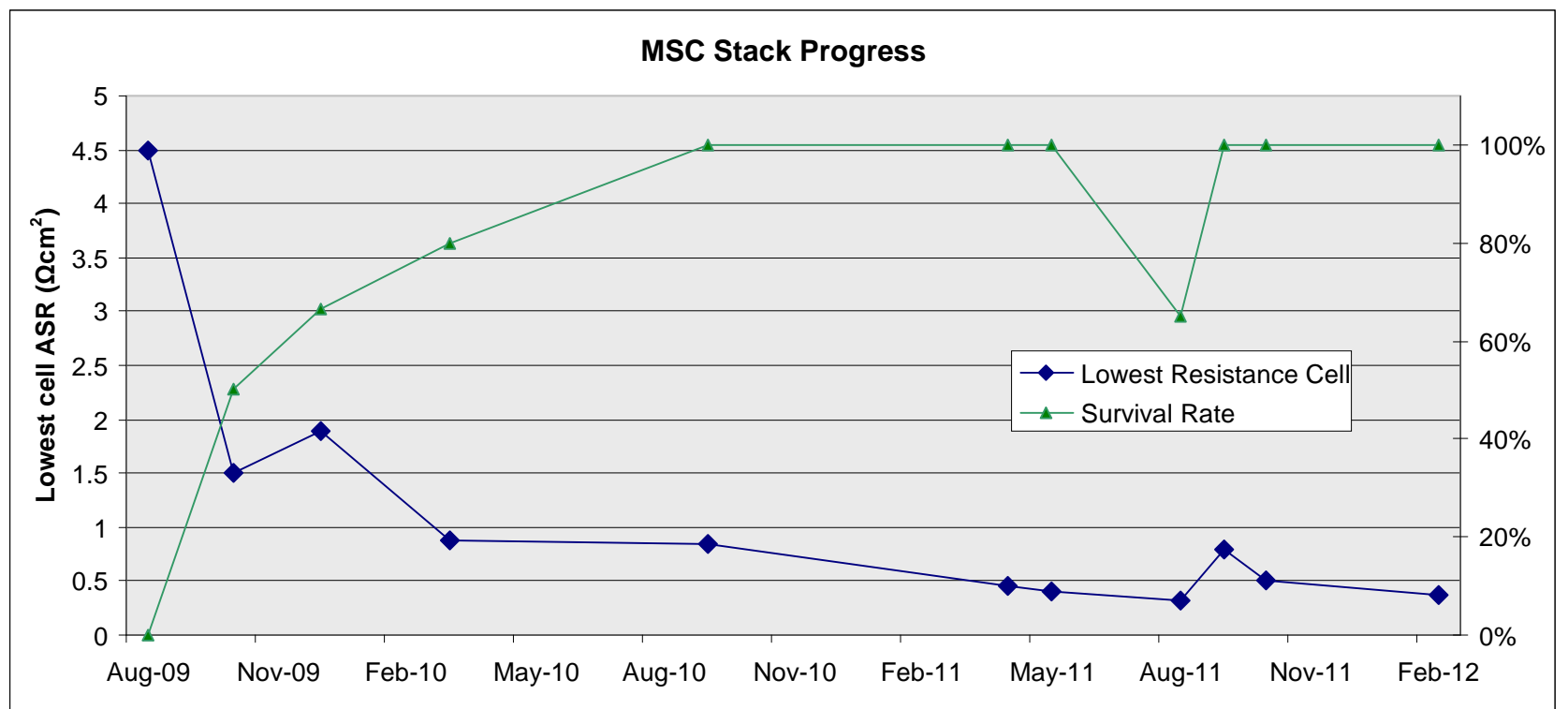

Figure 6: Improvements in ASR of MSCs in various stacks in the METSOFC consortium. Also shown are the portions of cells having stable performance after stack conditioning.

The knowledge gained from these incremental variations was applied to a larger stack, at the end of the METSOFC project. This final operating stack was made entirely of MSCs, 25 in total, all of which emerged from the conditioning procedure with high performance (Figure 7, below). This stack was tested at $450 \mathrm{~W}$ at $700^{\circ} \mathrm{C}$, representing the highest stack power output of this consortium and importantly benchmarks very high performance in the class of MSCs. Furthermore, the MSCs also had a low variability in performance, and they critically survived the first thermal cycling with overall small voltage loss. In short, the stack development at TOFC demonstrated that the cell-level performance of MSCs can be replicated in stack form with control and uniformity. 


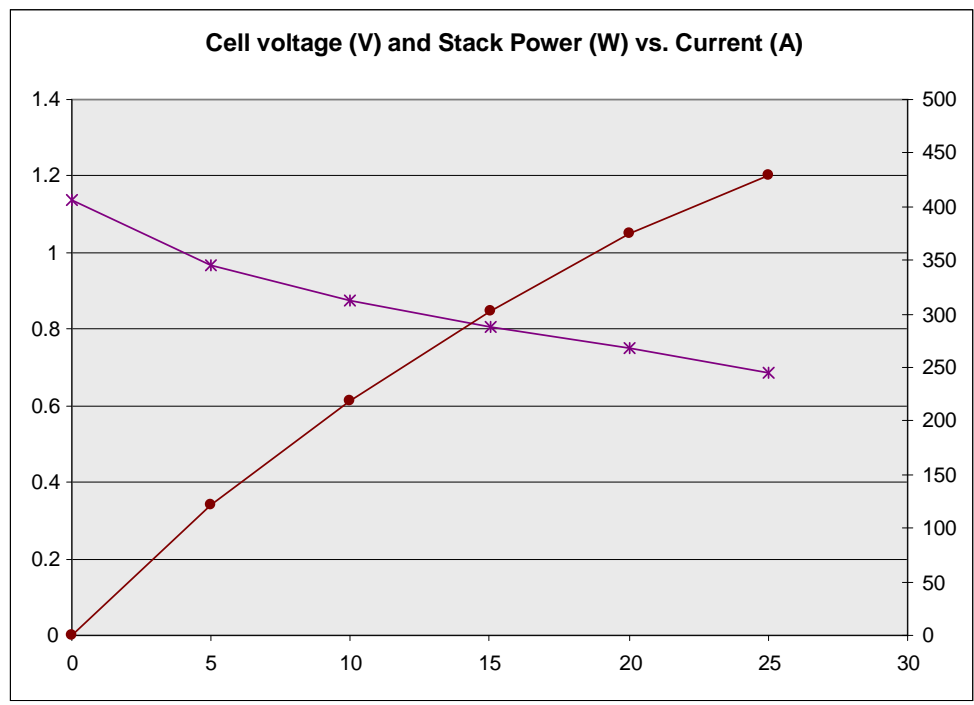

Figure 7: Voltage and Power curves of stack containing 25 MSCs.

In recent extended work, an improved procedure and MSC cathode were used for extended testing of a short stack. This has been tested so far over a 250 hour duration operating at $700^{\circ} \mathrm{C}$ on hydrogen under different loads. Figure 8 , below, shows an average of MSC voltages over the period of 150 hours during which the stack operated at a constant current density of $230 \mathrm{~mA} / \mathrm{cm}^{2}$. It can be seen that this early prototype stack operates with a degradation rate under $160 \mathrm{~m} \Omega \mathrm{cm}^{2} / \mathrm{kh}$. The primary cause of voltage loss is presumed to be related to the cell oxidation failure mode described in the above section on cell development. Future stack modifications will address leakages in order to minimize potential damage to the MSCs. Further stack work is also required over longer durations and under harsher operation in order to elicit and study failure mechanisms.

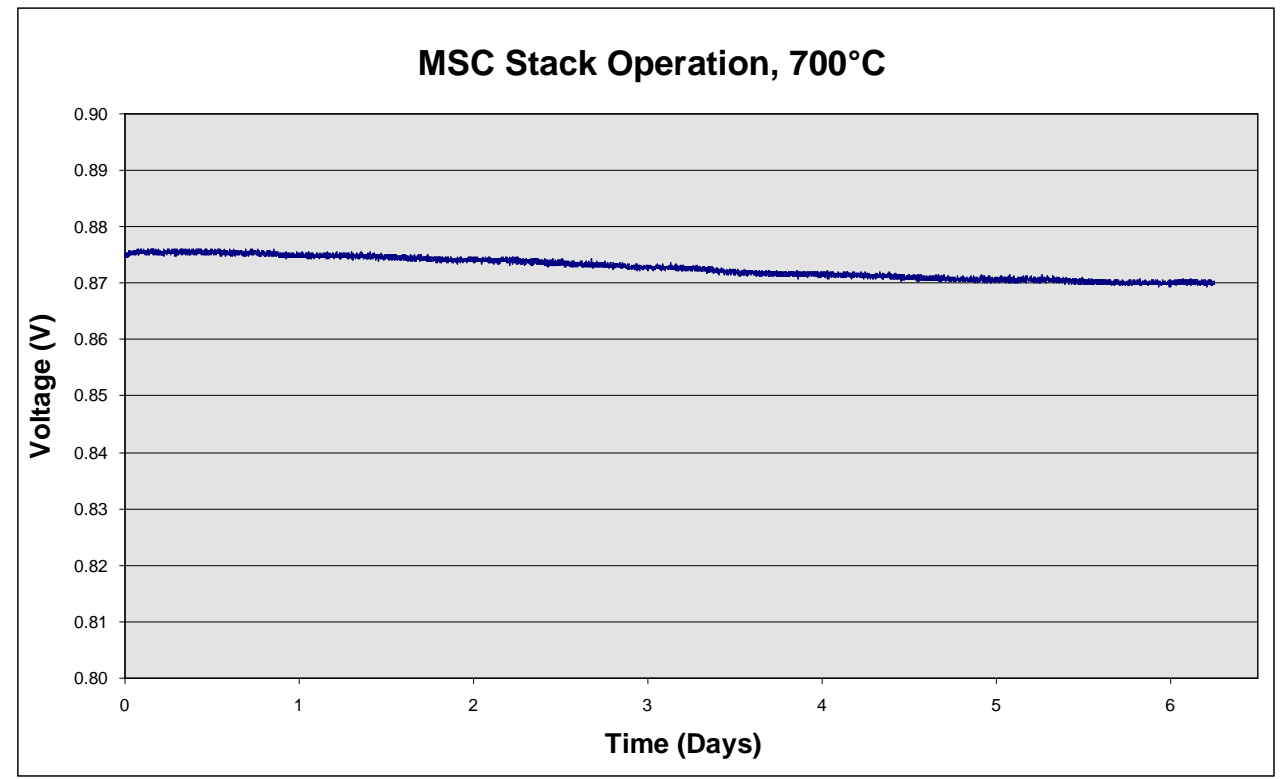

Figure 8: Average MSC voltage in an MSC stack, sample period of 150 hours at $700^{\circ} \mathrm{C}$ and $230 \mathrm{~mA} / \mathrm{cm}^{2}$. Two next-generation DTU cells were also in the stack but not included here. 


\section{Testing for System Context}

Some of the stacks developed at TOFC with DTU MSCs were characterized with extended testing at AVL. The primary goal of this aspect of the METSOFC consortium was to determine further stack durability qualities, including load cycling, behavior towards sulfur, simulated diesel reformate, and vibration testing. All these were observed, and by the project end, one stack was operated for a total of a few hundred hours and demonstrated the capability to thermal cycle multiple times.

The stack test performed on a stack containing a mixture of ASCs and MSCs yielded information about tolerance towards load cycles, redox cycles, and sulfur poisoning. The performance of the MSCs at $700^{\circ} \mathrm{C}$ with hydrogen was about $26 \mathrm{We} / \mathrm{Cell}(\sim 0.87 \mathrm{~V} @ 30 \mathrm{~A})$ and $17 \mathrm{We} / \mathrm{Cell}$ ( $\sim 0.7 \mathrm{~V} @ 25 \mathrm{~A}$ ) output with simulated diesel reformate-gas. The limiting factors for the performance tests were the ASC cells. Also at lower operating temperatures, e.g. $650^{\circ} \mathrm{C}$, the performance values of the MSC cells remained constant with hydrogen. With simulated diesel reformate gas, the performance of the MSC cells was slightly lower with about $16.5 \mathrm{We} /$ Cell. During the stack lifetime at both TOFC and AVL, six full thermal cycles were performed, from ambient temperature up to $700^{\circ} \mathrm{C}$. All MSC cell performed excellent without damage after the thermal cycles. Operation with $0.65 \mathrm{ppm}$ $\mathrm{H}_{2} \mathrm{~S}$ at $20 \mathrm{~A}$ constant load with simulated diesel reformate gas caused most of the MSCs to degrade. However, this response to sulfur poisoning was not conclusive, because the OCV was also affected, most likely due to a leakage in the stack as a consequence of more complex conditions than the type of the cells. The change in cell performance during these various tests is summarized in Figure 9, below. Over the various testing procedures, the stack operated a total of more than 300 hours.

\section{METSOFC Stack Test}

Base point 30A over test duration

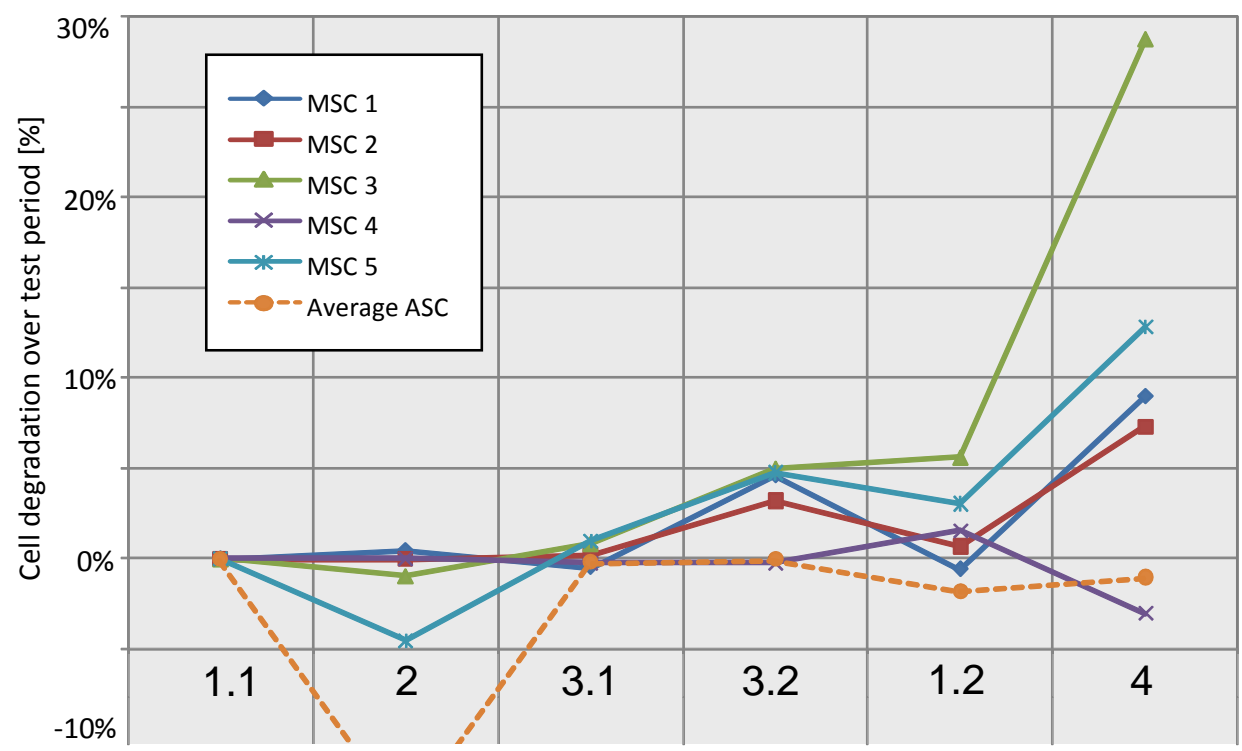

Figure 9: Percent performance loss at base point operation change at $30 \mathrm{~A}$ over the test period at AVL. (1) Base point validation, (2) Load Variation, (3) Thermal cycling, (4) Sulfur poisoning. 


\section{Conclusion}

The METSOFC project effectively obtained results and progress, in spite of many unpredicted challenges in the novel and complex metal supported cell technology. Most of the targeted performance values were fulfilled - some with even better results and a few slightly less than the target values. MSCs have been up-scaled from $4 \mathrm{~cm}^{2}$ to $144 \mathrm{~cm}^{2}$, and even a few cells with $300 \mathrm{~cm}^{2}$ foot prints have been produced to demonstrate the potential in the fabrication process. The ASR performance of the button cells tested have been improved to $<0.3 \Omega \mathrm{cm}^{2}$ measured at $650{ }^{\circ} \mathrm{C}$, which is better than the project target. The degradation rate has been improved from 4.5 to $0.9 \%$ per 1000 hours; and cell-level testing demonstrated significantly better red-ox cycle resistance than current anode supported cells. On stack level, ASR was improved from $2 \Omega \mathrm{cm}^{2}$ to $0.5 \Omega \mathrm{cm}^{2}$, operating at $700^{\circ} \mathrm{C}$ and lower. Stacks up to 25 cells have been assembled and tested.

As a spin off from METSOFC, a new EU FCH JU project METSAPP was launched at the end of 2011, aiming at further improvement of durability and lifetime for residential applications. Corrosion of the fine structured powder metal layer is governing the limited lifetime of the cells, while stack conditioning and sealing has revealed many unknown parameters that need to be further optimized. The work plans of the METSAPP project describes in details the road towards improvements of the METSOFC cell and stack technology. Furthermore, the cell and stacks developed in the two projects will be evaluated for potential implementation in the APU development project EU FCH JU DESTA.

Financial support by the EU project FP7-211940 (METSOFC) and The Danish National Advanced Technology Foundation is gratefully acknowledged.

\section{References}

1. P. Blennow, J. Hjelm, T. Klemensø, Å.H. Persson, S. Ramousse, M. Mogensen, Planar Metal-Supported SOFC with Novel Cermet Anode, Fuel Cells, 11, 661-668 (2011).

2. P. Blennow, J. Hjelm, T. Klemensø, S. Ramousse, A. Kromp, A. Leonide, A. Weber, Manufacturing and characterization of metal-supported solid oxide fuel cells, J. Power Sources, 196, 7117-7125 (2011).

3. T. Klemensø, J. Nielsen, P. Blennow, A.H. Persson, T. Stegk, B.H. Christensen, S. Sønderby, High performance metal-supported solid oxide fuel cells with Gd-doped ceria barrier layers, J. Power Sources, 196, 9459-9466 (2011).

4. P. Blennow, T. Klemensø, Å.H. Persson, K. Brodersen, A.K. Srivastava, B.R. Sudireddy, S. Ramousse, M. Mogensen, Metal-Supported SOFC with CeramicBased Anode, ECS Trans., 35 (1), 683-692 (2011). 